\title{
Alternative Disease Control Agents Induce Resistance to Blue Mold in Harvested 'Red Delicious' Apple Fruit
}

\author{
Guy de Capdeville, Charles L. Wilson, Steven V. Beer, and James R. Aist
}

First, third, and fourth authors: Department of Plant Pathology, Cornell University, Ithaca, NY 14853; and second author: U.S. Department of Agriculture-Agricultural Research Service, Appalachian Fruit Research Station, 45 Wiltshire Road, Kearneysville, WV 25430. Accepted for publication 18 April 2002.

\begin{abstract}
de Capdeville, G., Wilson, C. L., Beer, S. V., and Aist, J. R. 2002. Alternative disease control agents induce resistance to blue mold in harvested 'Red Delicious' apple fruit. Phytopathology 92:900-908.

Alternative control agents, including UV-type C (254 nm) irradiation, yeasts antagonistic to fungal growth, chitosan and harpin, were evaluated for their ability to induce resistance in cv. Red Delicious apple fruit against postharvest blue mold caused by Penicillium expansum. Freshly harvested and controlled atmosphere (CA)-stored fruit were treated with these agents at different doses and concentrations or with paired combinations of the agents. Treated fruit were inoculated with $P$. expansum 24, 48, or $96 \mathrm{~h}$ following treatment, and stored at $24^{\circ} \mathrm{C}$ in the dark. The fruit were evaluated for development of disease every 2 days for 14 days by measuring the diameter of lesions that formed. The area under the disease progress curve (AUDPC) was calculated and analyzed statistically. All treatments were effective in reducing the AUDPC; UV-C

ments than CA-stored fruit. There was a clear time-dependent response of the fruit to the treatments, in which treatments applied $96 \mathrm{~h}$ before inoculation provided the best results. In a few situations, the combinations of agents did provide an additive effect, but no synergistic effects were detected. Moreover, disease severity in fruit treated by any combination was markedly better than that in the controls. Although the combinations of treatments was overall less effective than the single treatments, they did provide significant reductions of the progress of disease in comparison with the controls. Because the fungus did not come into contact with any of the control agents, this study showed conclusively that the agents studied were able to induce resistance in the fruit rather than merely inhibit the pathogen directly. It also showed, for the first time, that harpin is able to induce resistance in harvested apple fruit. The use of these control agents may minimize the costs of control strategies and reduce the risks associated with the excessive use of fungicides in harvested apple fruit.
\end{abstract} was most effective, followed by harpin, chitosan, and the yeasts, respectively. Regardless of treatment, fresh fruit were more responsive to treat-
Additional keywords: Candida oleophila, C. saitoana, Malus domestica.
Postharvest diseases of apples are responsible for considerable losses that occur during the storage period. Blue mold, caused by Penicillium expansum Link., causes most of those losses (26). Depending on the apple cultivar, infections by this fungus may be initiated through wounds or through the stems $(23,26)$. The strategies used to control infections have been based on avoiding damage during harvest and processing, on sanitation, use of controlled atmosphere (CA)-storage, and control of storage temperature and relative humidity (26). However, the most used and effective strategy is the treatment of apples after harvest with fungicides, especially thiabendazole, which is sometimes combined with wide-spectrum fungicides such as Captan (21). Due to problems related to fungicide toxicity, development of fungicide resistance by pathogens, and potential harmful effects on the environment and human health, as well as the necessity to reduce losses while reducing the use of fungicides, new strategies for control have been proposed $(4,6,7)$. Alternative control measures such as the use of short wave (254 nm) UV irradiation (UV-C), natural compounds, and microbial antagonists have been evaluated as promising alternatives for control of postharvest diseases. These may directly affect pathogens or induce resistance mechanisms in fruit $(6,29,35)$. Under field conditions, many alternative control agents have provided limited success, which is often attributed to "uncontrollable" environmental conditions. However, the likelihood of success is greatly increased during the postharvest phase due to

Corresponding author: J. R. Aist; E-mail address: jra2@ cornell.edu

Publication no. P-2002-0617-01R

(c) 2002 The American Phytopathological Society better environmental control. Moreover, it is often easier to effectively apply alternative control agents while commodities are being processed after harvest.

Examples of recent success in controlling the damage caused by postharvest pathogens using biocontrol agents are provided by the results of El-Ghaouth (6), Wilson et al. (34), Mercier and Wilson (17), Sugar and Spotts (31), Droby et al. (5), and Janisiewicz and Bors (13). In some of these studies, wounds in apple fruit were treated with different biocontrol agents and inoculated with the fungal pathogen Botrytis cinerea, leading to a considerable reduction in lesion development. Control of plant diseases using yeast antagonists, UV-C irradiation, and natural compounds has complex and diverse modes of action. For yeast antagonists, the control process is dynamic and may involve the microecology of the pathogen and antagonist, antibiosis, as well as resistance responses of the host (4). UV-C irradiation, besides being germicidal and causing delayed ripening of fruit, elicits biochemical responses in host tissue that are relevant to disease control $(15,27)$. Chitosan, a high-molecular weight polysaccharide that is produced by alkaline deacetylation of chitin, effectively controls postharvest decay due to its effect on senescence and its ability to induce an increase in activity of enzymes such as chitinase and $\beta$-1,3-glucanases $(7,8)$. Natural compounds such as harpin and 2,6-dichloroisonicotinic acid can induce systemic acquired resistance in living plants (3). However, very few studies have been done to elucidate their ability to induce postharvest resistance in fruit. Although postharvest induced resistance has been much less studied than other control measures, it has been recognized as an important and manageable form of resistance in harvested fruit and vegetables (6). However, well-documented evidence to support this possible mode of action is limited, because to the extent of our 
knowledge, only the study by Mercier et al. (15) was done to evaluate postharvest induced resistance separately from other possible (direct) effects that biocontrol agents might have on the pathogen.

The primary objective of this work was to test the ability of two antagonistic yeasts, UV-C irradiation, chitosan, harpin, and combinations of these agents to induce resistance in apple fruit to blue mold and to study this effect apart from any direct effects of the control measures on the pathogen. Because very little is known about how fruit with different postharvest "ages" respond to such treatments, we investigated the ability of the biocontrol agents to induce resistance against blue mold in both freshly harvested and controlled atmosphere (CA)-stored apple fruit. The results should allow us to select among these control measures, or combinations thereof, those most suitable to be studied in more detail to determine possible structural and molecular mechanisms involved in the induced resistance process. In addition, these findings should provide practical information about the most appropriate time to treat the fruit with the different alternative control agents or their combinations to minimize blue mold in storage.

\section{MATERIALS AND METHODS}

Inoculum preparation. An isolate (USCU1) of Penicillium expansum Link. kept in the U.S. Department of Agriculture, Agricultural Fruit Research Station collection (Kearneysville, WV) was used as the source of inoculum for the experiments. The pathogenicity of the isolate was checked by inoculating cv. Red Delicious apple fruit (Malus domestica Borkh.). From lesions formed in those inoculated fruit, pieces of tissue were removed from the edge of the lesions, immersed in $70 \%$ ethanol for $1 \mathrm{~min}$, transferred to a solution of $1 \%$ sodium hypochlorite for $1 \mathrm{~min}$, washed three times for 2 min each in sterile distilled water, blotted on sterile filter paper, and plated on potato dextrose agar (PDA) medium amended with $0.1 \%$ streptomycin. The plates were placed in a growth chamber at $24^{\circ} \mathrm{C}$, and after colonies were formed, disks of mycelium were removed from the edge of the colony and transferred to assay tubes containing PDA plus $0.1 \%$ streptomycin, allowed to grow for 3 days at $24^{\circ} \mathrm{C}$, and stored in the refrigerator at $5^{\circ} \mathrm{C}$. These stock cultures were tested for pathogenicity every 4 months. The stocks were used for generating new 10-dayold colonies on PDA plus $0.1 \%$ streptomycin from which spores were collected in sterile water amended with $0.01 \%$ Tween 20 . The final concentration of the spore suspension was adjusted with a hemacytometer.

Preparation of the control agents. Chitosan. Low molecular weight chitosan (Aldrich Chemical Company, Inc., Milwaukee, WI) was used to prepare aqueous solutions at concentrations of $0.25,0.5,1.0$, and $2.0 \%$ (wt/vol). Acetic acid was used to bring the $\mathrm{pH}$ of the solution to approximately 6 to allow the solubilization of the compound.

Harpin. A laboratory preparation of partially purified harpin from Erwinia amylovora provided by S. V. Beer was used to prepare aqueous solutions at concentrations of $10,20,40$, and $80 \mu \mathrm{g} / \mathrm{ml}$. Harpin was prepared as described by Dong et al. (3). Escherichia coli strain DH5 $\alpha$, harboring plasmid pCPP2139, which contains the hrpN gene of Erwinia amylovora in the expression vector pCPP50 carrying a selective marker for resistance to ampicillin, was grown in liquid high-nutrient growth media made of TB DRY (MO BIO Laboratories, Inc., Solana Beach, CA) containing $1 \mathrm{mM}$ isopropyl- $\beta$-D-thiogalactoside and $200 \mu \mathrm{g}$ of ampicillin per $\mathrm{ml}$ in a shaker (New Brunswick Scientific, Edison, NJ) at $30^{\circ} \mathrm{C}$ for 16 to $20 \mathrm{~h}$ to optical density at $620 \mathrm{~nm}\left(\mathrm{OD}_{620}\right) \geq 2.0$. Bacterial cells were precipitated by centrifuging at 7,000 $\times g$ for $15 \mathrm{~min}$, suspended in Tris buffer (20 mM, pH 9.0), and incubated with $1 \mu \mathrm{l}$ of Ready-Lyse (Epicenter Biotechnologies, Rockford, IL) per ml and $100 \mu \mathrm{g}$ of phenylmethylsulfonyl fluoride (PMSF prepared in dimethyl formamide) per $\mathrm{ml}$ on ice for $10 \mathrm{~min}$. Bacterial cells were sonicated twice for $10 \mathrm{~min}$ in an ice bath, using a $1.5-\mathrm{cm}$ probe driven by the Cell Disruptor (Model 305; Branson Ultrasonics Corp., Danbury, CT). The resulting bacterial lysate was mixed with a third addition of PMSF and centrifuged at $10,000 \times g$ for $20 \mathrm{~min}$. The supernatant was collected, heated in a boiling water bath for $10 \mathrm{~min}$, allowed to cool, and centrifuged at $12,000 \times g$ for $20 \mathrm{~min}$. The resulting supernatant, regarded as harpin preparation, was assayed for harpin protein by electrophoresis in a sodium dodecyl sulfate-polyacrylamide gel and for hypersensitive responseeliciting activity.

Yeast antagonists. Two yeasts species, Candida saitoana (isolate US-240, NRRL Y-21022) and C. oleophila (isolate US-182, NRRL Y-18846), provided by C. L. Wilson, were used in this work. The yeasts were grown under agitation $(125 \mathrm{rpm})$ on a controlled environment incubator shaker (New Brunswick Scientific) in $50-\mathrm{ml}$ Erlenmeyer flasks containing $30 \mathrm{ml}$ of yeast maltose broth medium (Difco Laboratories, Detroit) for $48 \mathrm{~h}$ at $26^{\circ} \mathrm{C}$ in the dark. The yeasts cells were separated from the medium by centrifuging at 3,000 rpm in a Sorvall centrifuge (Sorvall SS-34 Rotor; Sorvall Instruments, Newtown, CT) for $12 \mathrm{~min}$. The pellet formed was resuspended twice in sterile, high purity water. The final concentration of each isolate was adjusted to $10^{8} \mathrm{CFU} \mathrm{ml^{-1 }}$ with a hemacytometer (11).

$U V-C$ irradiation. The UV-C dose of $7.5 \mathrm{~kJ} / \mathrm{m}^{2}$ chosen for this experiment was based on preliminary tests done prior to the execution of the experiments and on the results by Stevens et al. (29) and Wilson et al. (33). To calculate the appropriate exposure time, we adapted the procedure proposed by Stevens et al. (27). Four UV lamps (Model G15T8; 115 V, 15 W, Sankyo Denki, Japan) emitting a wavelength at $254 \mathrm{~nm}$ were used. Each of the lamps had a diameter of $2.5 \mathrm{~cm}$ and a length of $48 \mathrm{~cm}$. The lamps were placed $20 \mathrm{~cm}$ from the fruit in a manner that generated an irradiation area of $250 \mathrm{~cm}^{2}$, in which 25 fruit could be irradiated each time the bulbs were turned on. To make sure that the whole fruit surface received the appropriate dose, the exposure time necessary to irradiate the whole fruit was divided into four subdoses, which were applied to the four sides of the fruit by rotating them three times. The fruit were also repositioned randomly within the exposure field. A timer connected to the UV source controlled the exposure time at each rotation of the fruit, and the UV-C dose rate was measured with a digital radiometer (UVX; Ultraviolet Products, Inc., San Gabriel, CA).

Source of fruit. The freshly harvested or CA-stored apple fruit of cv. Red Delicious used in this experiment were harvested at the Cornell University Orchard (Ithaca, NY) and were either immediately used in the experiments or stored in a CA chamber under $2.5 \% \mathrm{O}_{2}$ and $2.5 \% \mathrm{CO}_{2}$ for 3 months to be used in later experiments. No preharvest sprays were applied to the fruit within 1 month before harvest.

Effect of the agents applied singly on the progress of blue mold. A series of separate assays were done to evaluate the ability of each control agent to control blue mold of cv. Red Delicious apples. Fruit were treated with different concentrations (chitosan or harpin), doses (UV-C irradiation), or species (yeasts). Three different inoculation times (24, 48, and $96 \mathrm{~h}$ after initial treatment) were tested to estimate roughly when the onset of resistance takes place. Freshly harvested and CA-stored fruit were used in the experiments to determine whether the physiological "age" of the fruit affected their ability to respond to the treatments.

Ten fruit per treatment were harvested or removed from the CA storage, brought to the lab, washed with high purity water, wiped off with Kimwipes tissue (Kimberly-Clark Corporation, Roswell, GA), and placed on commercial paper storage trays inside a growth chamber at $24^{\circ} \mathrm{C}$ and $80 \%$ relative humidity. After acclimatizing for $4 \mathrm{~h}$, the fruit were treated with the control agents as follows. UV-C irradiation was applied to the whole fruit surface as described before. The remaining control agents were applied to the fruit by placing $50-\mu \mathrm{l}$ drops of the respective solution or suspension in four equidistant points on the fruit surface separated 
from each other as the four vertices of a square with $2 \mathrm{~cm}$ sides (Fig. 1). Without any spreading or redistribution, the drops dried within about $2 \mathrm{~h}$ in the same spot they were applied. At 24, 48, or $96 \mathrm{~h}$ after the treatment with the putative control agents, a wound $2 \mathrm{~mm}$ deep and $2 \mathrm{~mm}$ in diameter was made in the center of the area surrounded by the four treatment points in each fruit (Fig. 1). The wound was then flooded with $20 \mu \mathrm{l}$ of a spore suspension of $P$. expansum at $10^{4}$ spores per $\mathrm{ml}(\approx 200$ spores per wound). Development of disease was evaluated seven times (every 2 days for 14 days) by measuring the diameter of the lesions formed. These measurements were used to calculate the area under the disease progress curve (AUDPC) using the equation proposed by Shaner and Finney (25):

$$
\operatorname{AUDPC}=\Sigma\left[\left(y_{i}+y_{i+1}\right) / 2 \times\left(t_{i+1}-t_{i}\right)\right]
$$

where $y_{i}$ is the diameter of a lesion at time $t_{i}$, in days, and $y_{i+1}$ is the diameter of the lesion at time $t_{i+1}$.

We were aware that the yeasts might be able to grow from the area where they were applied to the area where the inoculation wound was made. Therefore, during preliminary assays conducted before the experiments described previously, we tested the area around the inoculation site for the presence of yeast cells of the species studied. For this purpose, we collected a $5 \mathrm{~mm}$ wide ring of peel tissue immediately adjacent to the edge of the wound, including the wound, from 20 fruit treated with the yeasts in the same manner described previously (two replications of five fruit each per yeast species). The peel samples were collected 12 days after treatment with the yeasts, individually macerated in a sterile mortar using $1 \mathrm{ml}$ of sterile water, and filtered with sterile cheesecloth. Three serial, 10-fold dilutions were made of each preparation. A portion of each dilution $(0.5 \mathrm{ml})$ was plated on yeast-maltose-agar medium, and the plates were stored in an incubator at $26^{\circ} \mathrm{C}$. At 24,48 , and $72 \mathrm{~h}$, they were evaluated for the presence of colonies (adapted from Dhingra and Sinclair [2]). Moreover, to verify that, in the experiments described in this study, the yeasts did not grow to the point that they would reach the inoculation wound, the same procedure described previously was applied to five randomly chosen fruit per yeast species.
Effect of combination of agents on the progress of blue mold. Fruit were treated with the control agents singly or in combinations of two to evaluate the possible existence of additive or synergistic effects of the combinations. The combinations and concentrations of the agents used were determined based on the results of experiment I. UV-C was applied at the dose of $7.5 \mathrm{~kJ} / \mathrm{m}^{2}$, harpin was applied at $80 \mathrm{mg} / \mathrm{liter}$, chitosan at $1 \%$ (wt/vol), and the yeast $C$. saitoana at a concentration of $10^{8} \mathrm{CFU} / \mathrm{ml}$. The control agents were combined with each other in pairs, making a total of six combinations. They were applied in the following order: (i) whenever UV-C was used, it was applied first and $2 \mathrm{~h}$ later the other agent was applied; (ii) whenever the yeast was used, it was applied $2 \mathrm{~h}$ after the first agent was applied to make sure that the other agent had dried, thus avoiding any significant dilution of the concentration wanted; and (iii) harpin was always applied first, except when combined with UV-C, because the irradiation treatment would rapidly degrade it.

As described for the previous experiment, at 24, 48, or $96 \mathrm{~h}$ after the treatments with the control agents, a wound was made in the center of the area surrounded by the four treatment points of each fruit, and this wound was then flooded with $20 \mu \mathrm{l}$ of a spore suspension of $P$. expansum at $10^{4}$ spores per $\mathrm{ml}(\approx 200$ spores per wound). Development of disease was assessed as previously described.

Data analysis: yeasts and UV-C analyses. The data for the experiments with the yeasts and UV-C were analyzed as a factorial design using PROC GLM of SAS (SAS Institute, Cary, NC) and following the statistical model described below (14). The least square means (LSMeans) were used to compare the treatment means. If the interaction effect was significant $(P<0.05)$, then each factor was analyzed within each level of the other factor using the SLICE option of the LSMeans and orthogonal contrasts using the following model:

$$
Y_{i j k}=\mu+\alpha_{i}+\beta_{j}+(\alpha \beta)_{i j}+\varepsilon_{i j k}
$$

where $Y_{i j k}$ is the AUDPC calculated for the two types of fruit used in the experiments (fresh or CA-stored), $\mu$ is the overall mean, $\alpha_{i}$ is the fixed effect of treatments either of yeasts (water, US-182, and US-240) or UV-C irradiation (control and UV treated), $\beta_{j}$ is

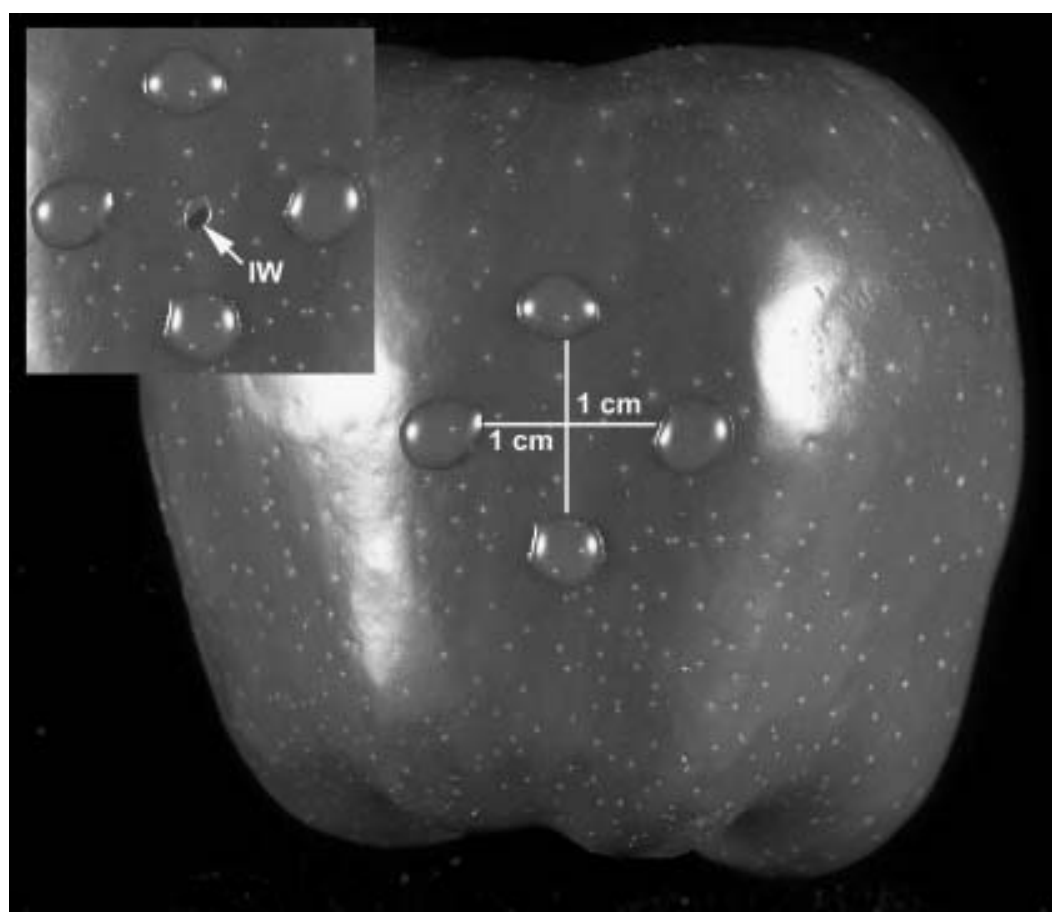

Fig. 1. Representation of the application of the agents on the fruit surfaces. The 50- $\mu$ d drops shown contain a specific agent at the concentration used in each experiment, and they were placed approximately $1 \mathrm{~cm}$ from the inoculation wound (IW). 
the fixed effect of days after inoculation (24, 48, and 96 days), $(\alpha \beta)_{i j}$ is the interaction, and $\varepsilon_{i k j}$ is the random error with an independent identical distribution $\mathrm{N} \sim\left(0, \sigma^{2}\right)$. Additionally, for yeast analysis, a regression analysis using PROC GLM and SOLUTION option of SAS was performed to identify common regressions among treatments as described by the statistical model below (18):

$$
Y_{i j k}=\beta_{0}+\beta_{1} X_{i 1}+\beta_{2} X_{i 2}+\beta_{3} X_{i 2}{ }^{2}+\beta_{4} X_{i 1} X_{i 2}+\beta_{5} X_{i 1} X_{i 2}^{2}+\varepsilon_{i}
$$

where $Y_{i j k}$ is the AUDPC for fresh and CA-stored fruit, $X_{i 1}$ is treatment effects, $X_{i 2}$ is day effects, $\beta_{0}, \ldots \beta_{5}$ are the coefficients of the regression, and $\varepsilon_{i}$ is the random error with an independent identical distribution $\mathrm{N} \sim\left(0, \sigma^{2}\right)$.

Chitosan and harpin analyses. A regression analysis using PROC GLM and the SOLUTION option of SAS was performed to derive and compare the regression coefficients for levels of concentration of either chitosan $(0,0.25,0.5,1$, and $2 \%)$ or harpin
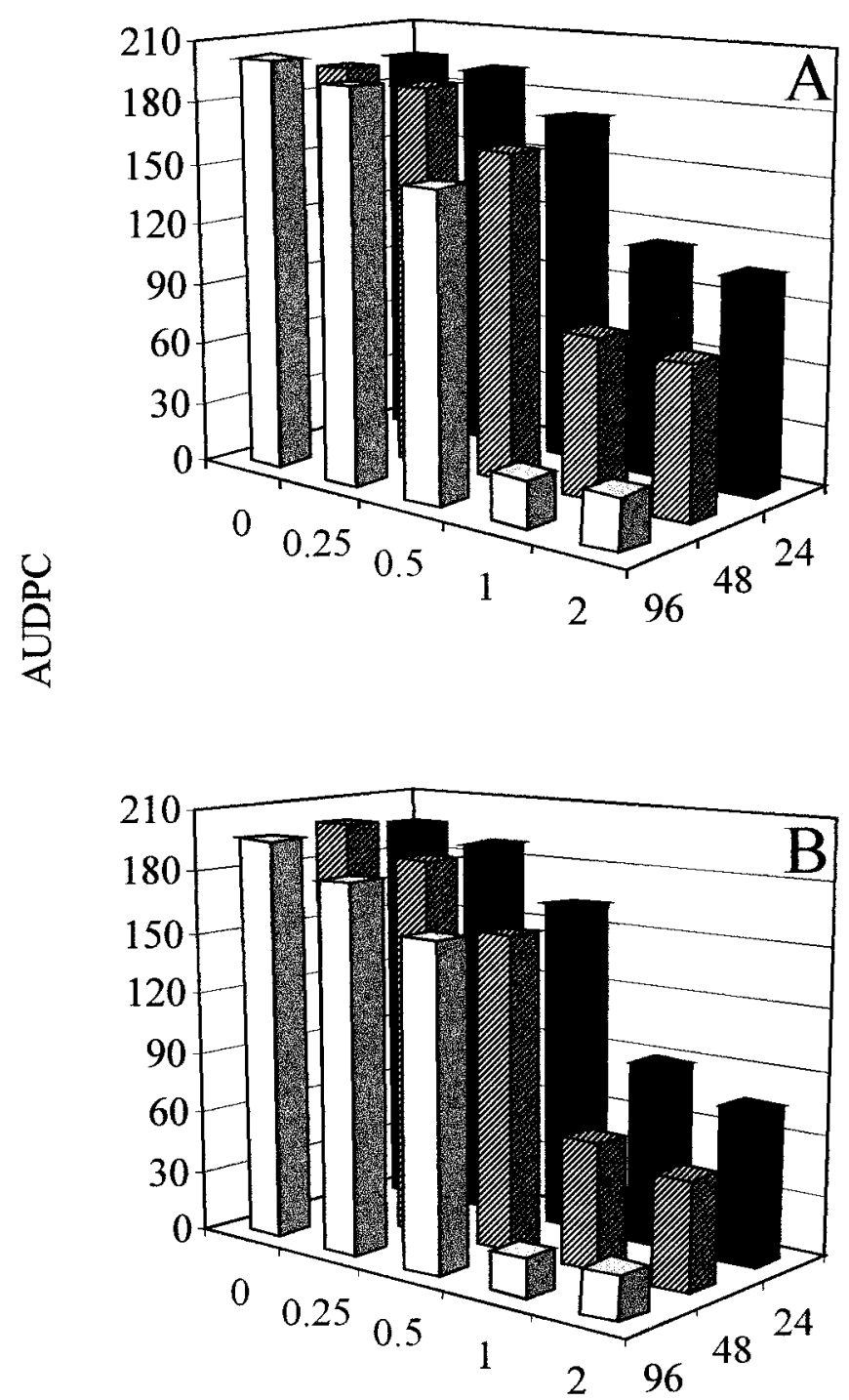

Chitosan (\%)

Time (h)

Fig. 2. Effect of chitosan on the area under the disease progress curve (AUDPC) of blue mold of cv. Red Delicious apple fruit treated with chitosan at five different concentrations and inoculated with Penicillium expansum at 24, 48, and $96 \mathrm{~h}$ after treatment. A and B, First $(P<0.0023$; $\left.R^{2}=0.80\right)$ and second $\left(P<0.0001 ; R^{2}=0.90\right)$ repetitions of the assay with fresh fruit.
$(0,10,20,40$, and $80 \mu \mathrm{g} / \mathrm{ml})$ and days of inoculation $(24,48$, and 96 days) as described by the statistical model (18):

$$
\begin{gathered}
Y_{i}=\beta_{0}+\beta_{1} X_{i 1}+\beta_{2} X_{i 1}{ }^{2}+\beta_{3} X_{i 1}^{3}+\beta_{4} X_{i 2}+\beta_{5} X_{i 2}{ }^{2}+\beta_{6} X_{i 1} X_{i 2}+\beta_{7} X_{i 1}{ }^{2} X_{i 2}+ \\
\beta_{8} X_{i 1}{ }^{3} X_{i 2}+\beta_{9} X_{i 1} X_{i 2}{ }^{2}+\beta_{10} X_{i 1}{ }^{2} X_{i 2}{ }^{2}+\beta_{11} X_{i 1}{ }^{3} X_{i 2}{ }^{2}+\varepsilon_{i}
\end{gathered}
$$

where $Y_{i j k}$ is the AUDPC for fresh and CA-stored fruit, $X_{i 1}$ is either chitosan concentration $(0,0.25,0.5,1$, and $2 \%)$ or harpin concentration $(0,10,20,40$, and $80 \mu \mathrm{g} / \mathrm{ml})$ effects, $X_{i 2}$ is day effects $\left(24,48\right.$, and 96 days), $\beta_{0}, \ldots \beta_{11}$ are the coefficients of the regression, and $\varepsilon_{i}$ is the random error with an independent identical distribution $\mathrm{N} \sim\left(0, \sigma^{2}\right)$.

Selected treatment combinations. This experiment was analyzed as a factorial design using PROC GLM of SAS following the statistical model described below (14). The LSMeans were used to compare the treatment (control, UV, US-240, chitosan, harpin, UV + US-240, UV + chitosan, UV + harpin, yeast + chitosan, yeast + harpin, and chitosan + harpin) means. If the interac-
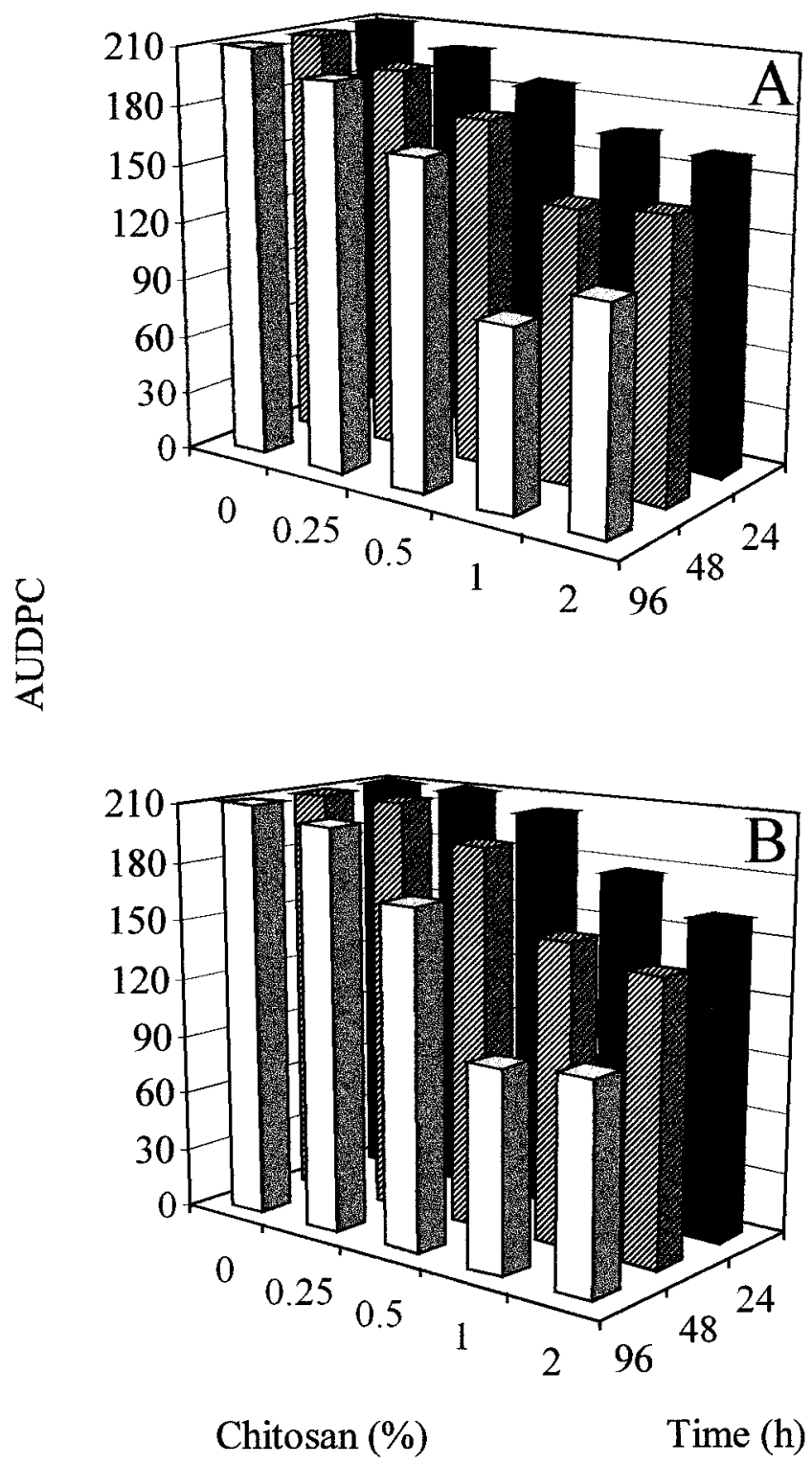

Fig. 3. Effect of chitosan on the area under the disease progress curve (AUDPC) of blue mold of cv. Red Delicious apple fruit treated with chitosan at five different concentrations and inoculated with Penicillium expansum at 24, 48, and $96 \mathrm{~h}$ after treatment. A and B, First $\left(P=0.0003 ; R^{2}=0.72\right)$ and second $\left(P=0.0315 ; R^{2}=0.78\right)$ repetitions of the assay with controlled atmosphere-stored fruit. 
tion effect was significant $(P<0.05)$, each factor was analyzed within each level of the other factor using the SLICE option of the LSMeans and some orthogonal contrasts of interest:

$$
Y_{i j k}=\mu+\alpha_{i}+\beta_{j}+(\alpha \beta)_{i j}+\varepsilon_{i j k}
$$

where $Y_{i j k}$ is the AUDPC for fresh and CA-stored fruit, $\mu$ is the overall mean, $\alpha_{i}$ is the fixed effect of treatments, $\beta_{j}$ is the fixed effect of days after inoculation (24, 48, and 96 days), $(\alpha \beta)_{i j}$ is the interaction, and $\varepsilon_{i k j}$ is the random error with an independent identical distribution $\mathrm{N} \sim\left(0, \sigma^{2}\right)$.

\section{RESULTS}

Effects of the individual control agents on the progress of blue mold-chitosan. The progress of blue mold on inoculated apple fruit treated with chitosan was significantly reduced in both the freshly harvested (Fig. 2A $\left[P<0.0023 ; R^{2}=0.80\right]$ and Fig. $2 \mathrm{~B}$ $\left[P<0.0001 ; R^{2}=0.90\right]$ ) and the CA-stored fruit (Fig. 3A $[P=$
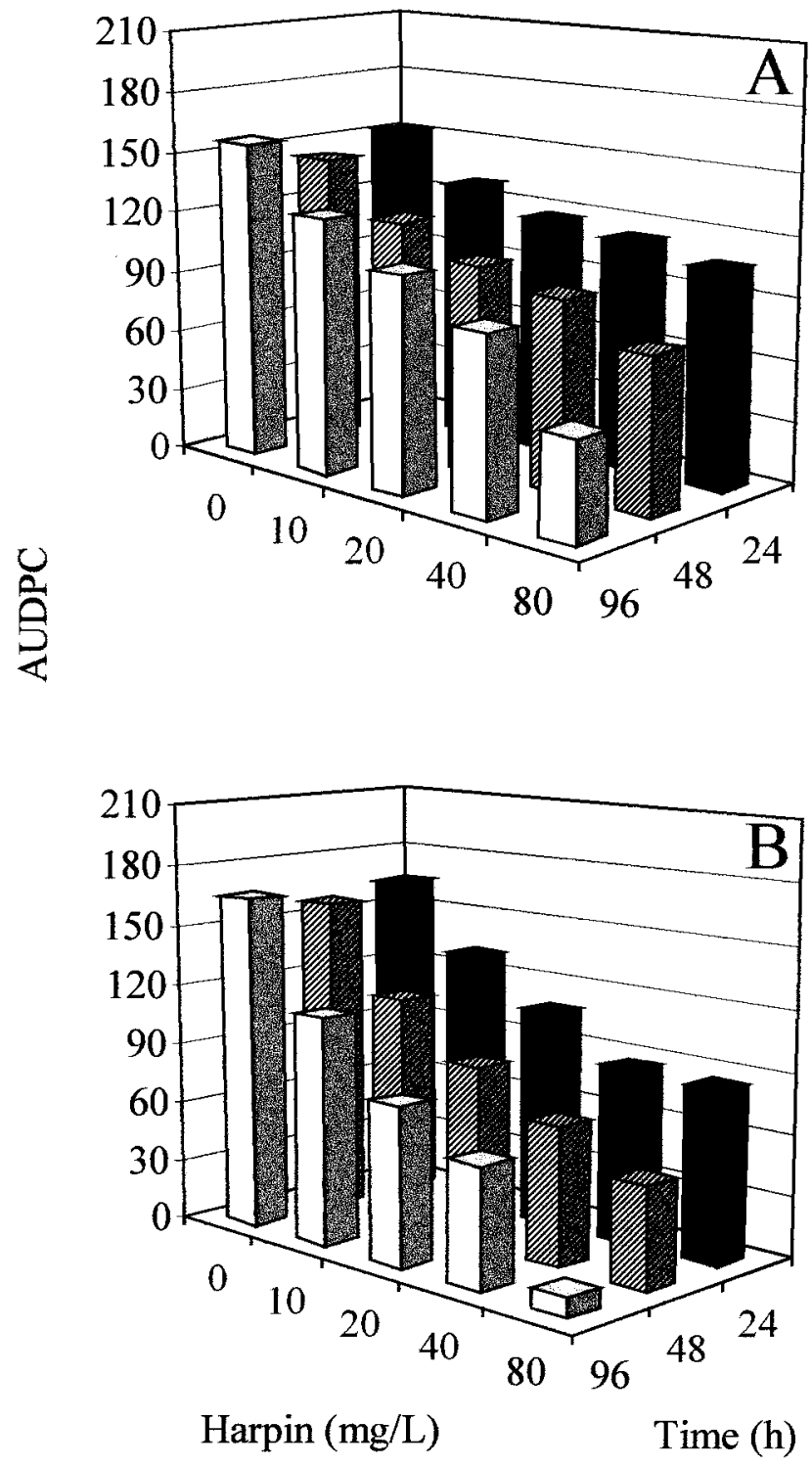

Fig. 4. Effect of harpin on the area under the disease progress curve (AUDPC) of blue mold of cv. Red Delicious apple fruit treated with chitosan at five different concentrations and inoculated with Penicillium expansum at 24, 48, and $96 \mathrm{~h}$ after treatment. A and B, First $(P<0.0001$; $\left.R^{2}=0.70\right)$ and second $\left(P=0.0301 ; R^{2}=0.78\right)$ repetitions of the assay with fresh fruit.
0.0003; $\left.R^{2}=0.72\right]$ and Fig. 3B $\left.\left[P=0.0315 ; R^{2}=0.78\right]\right)$. The effect of chitosan on fresh fruit was much more pronounced than on stored fruit. Greater reductions of AUDPC were observed for the concentrations of 1 and $2 \%$ and for inoculation times of 48 and $96 \mathrm{~h}$. Interactions between inoculation time and concentration were detected, such that fruit treated with concentrations of 1 and $2 \%, 96 \mathrm{~h}$ before inoculation, had the least disease. The tendency of reduced AUDPC with increasing time to inoculation and chitosan concentration was also observed in the assays where CAstored apples were used (Fig. 3A and B). However, the reduction was much less dramatic, especially for fruit treated 24 and $48 \mathrm{~h}$ before inoculation, than with freshly harvested fruit.

Harpin. Treatments with harpin also resulted in a time versus concentration-dependent response (Figs. 4 and 5). In contrast to treatment with chitosan, treatment with harpin significantly reduced AUDPC, even at the lowest concentration. The greatest effect was observed on fresh fruit treated with $80 \mu \mathrm{g} / \mathrm{ml}$ and inoculated $96 \mathrm{~h}$ later. Overall, there were no significant differences among the concentrations with inoculation times of 48 and 96 h (Fig. 4 A $[P<$
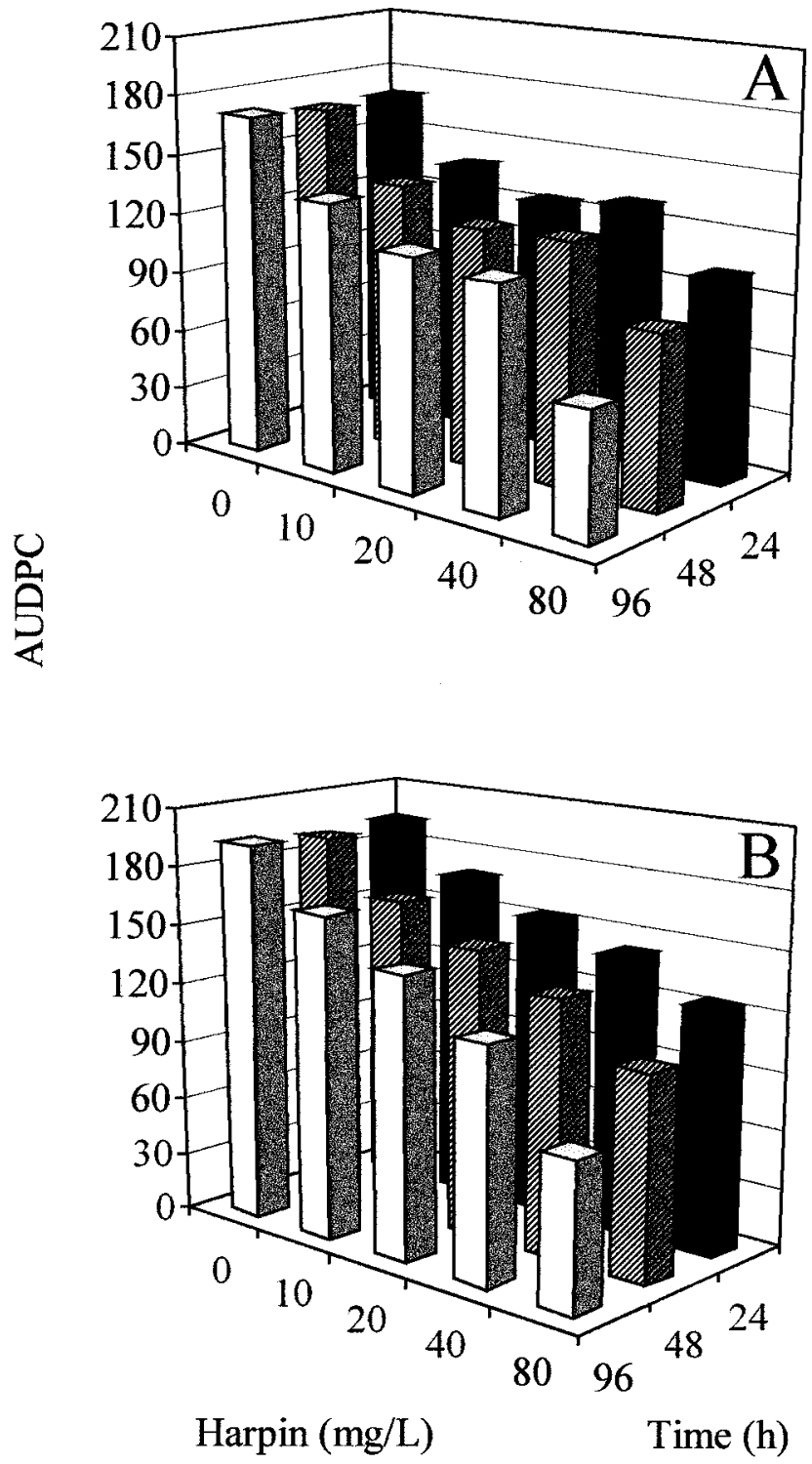

Fig. 5. Effect of harpin on the area under the disease progress curve (AUDPC) of blue mold of cv. Red Delicious apple fruit treated with chitosan at five different concentrations and inoculated with Penicillium expansum at 24, 48, and $96 \mathrm{~h}$ after treatment. A and B, First $\left(P<0.0001 ; R^{2}=0.73\right)$ and second $\left(P<0.0001 ; R^{2}=0.76\right)$ repetitions of the assay with controlled atmosphere-stored fruit. 
$\left.0.0001 ; R^{2}=0.70\right]$ and Fig. 4B $\left.\left[P=0.0301 ; R^{2}=0.78\right]\right)$. In addition, the effect of the treatments was slightly greater in the second repetition of the assay with fresh fruit (Fig. 4B). There was an effect of the treatments on CA-stored fruit as well, but overall, the stored fruit responded less intensely to the treatments (Fig. 5A $\left[P<0.0001 ; R^{2}=0.73\right]$ and Fig. 5B $\left.\left[P<0.0001 ; R^{2}=0.76\right]\right)$ than the fresh fruit.

Yeast antagonists. The two yeasts species differed considerably in their ability to induce resistance to blue mold (Table 1). For C. saitoana, reduction of AUDPC was significant for all inoculation times in both repetitions of the experiment with fresh fruit. This yeast reduced the progress of the disease more effectively when applied to the fruit 48 or $96 \mathrm{~h}$ before inoculation with $P$. expansum than when applied $24 \mathrm{~h}$ before inoculation. Treatment with $C$. saitoana also resulted in a smaller AUDPC than did the controls and $C$. oleophila in the repetitions of the experiments with fresh or CA-stored fruit. However, treatment with C. oleophila differed from the controls for inoculation times at 24 and $96 \mathrm{~h}$ with fresh fruit, and only for the inoculation time of $24 \mathrm{~h}$ with CA-stored fruit (Table 1). Analyzing the data of the treatments individually indicated that treating fruit $96 \mathrm{~h}$ before inoculation provided the best control. Based on reductions in the AUDPC, treatment with $C$. oleophila did not consistently reduce the AUDPC, except for the inoculation time at $96 \mathrm{~h}$ in the repetition of the experiment with fresh fruit, and for the inoculation time at $24 \mathrm{~h}$ both times the experiment with CA-stored fruit was conducted (Table 1). Upon testing the wounds and areas close to the edge of these wounds for the presence of yeast cells, we were able to confirm that although a few fungi and bacteria were isolated, mostly $P$. expansum, no yeast cells were recovered from the edge of or inside the wounds, indicating that, at least in the samples tested, no yeast growth occurred in that area.

UV-C irradiation. Treating fruit with UV-C irradiation considerably reduced the progress of the disease. This effect was noticeable even when fruit were treated only $24 \mathrm{~h}$ before inoculation (Table 2). Although treatment of the fruit $24 \mathrm{~h}$ before inoculation greatly reduced the AUDPC, treating the fruit 48 and $96 \mathrm{~h}$ before inoculation provided the greatest reduction in AUDPC. No differences were detected among the treatments for the 48 and $96 \mathrm{~h}$ inoculation times. CA-stored fruit were significantly less responsive to UV-C than fresh fruit. However, the tendency of reducing AUDPC with increasing time between treatment and inoculation was still present in the assays with CA-stored fruit (Table 2).

Effect of combinations of treatments on the progress of blue mold. For most of the agents used singly or in combinations, there was an effect of time of application of treatment before inoculation. Overall, fruit treated 48 or $96 \mathrm{~h}$ before inoculation developed less disease than fruit treated $24 \mathrm{~h}$ before inoculation (Fig. 6). However, even for fruit treated $24 \mathrm{~h}$ before inoculation, the disease progress was considerably less than for the controls. Overall, all treatments generated a significantly smaller AUDPC than the controls for all inoculation times. Very similar responses were observed when the experiment was repeated (data not shown).

Contrasting the means of the single treatments with the means of the combination of treatments clearly suggested that there was no synergistic effect of the combination of treatments. However, in a few situations, some additive effects were detected. For example, combinations of UV-C plus chitosan and C. saitoana plus chitosan generated a smaller AUDPC for the inoculation time at $48 \mathrm{~h}$ (Table 3). Treating fruit with UV-C alone at $24 \mathrm{~h}$ before inoculation was more effective than treating the fruit with any of the combination of treatments at the same time. At $48 \mathrm{~h}$, treatment with UV-C alone did not differ from treatment with combinations of UV-C plus $C$. saitoana, UV-C plus chitosan, or from $C$. saitoana plus chitosan. At $96 \mathrm{~h}$, treatment with UV-C alone did not differ from treatment with UV-C plus $C$. saitoana or UV-C plus chitosan. All the other combined treatments had a greater AUDPC than did treatments with UV-C alone at all inoculation times (Table 3). When compared with the combined treatments, the single treatments using C. saitoana, chitosan, or harpin were, in general, slightly better than or not different from the combined treatments.

TABLE 1. Influence of yeast antagonists on the progress of blue mold of cv. Red Delicious apples

\begin{tabular}{|c|c|c|c|c|c|c|c|}
\hline \multirow[b]{2}{*}{ Treatments } & \multirow[b]{2}{*}{ Time $^{\mathrm{y}}$} & \multicolumn{3}{|c|}{ Repetition $\mathrm{I}^{\mathrm{z}}$} & \multicolumn{3}{|c|}{ Repetition $\mathrm{II}^{\mathrm{z}}$} \\
\hline & & $\begin{array}{l}\text { Control } \\
\text { AUDPC }\end{array}$ & $\begin{array}{c}\text { Candida oleophila } \\
\text { AUDPC }\end{array}$ & $\begin{array}{c}\text { Candida saitoana } \\
\text { AUDPC }\end{array}$ & $\begin{array}{l}\text { Control } \\
\text { AUDPC }\end{array}$ & $\begin{array}{c}\text { Candida oleophila } \\
\text { AUDPC }\end{array}$ & $\begin{array}{c}\text { Candida saitoana } \\
\text { AUDPC }\end{array}$ \\
\hline \multirow[t]{3}{*}{ Fresh } & 24 & $217 \mathrm{Aa}$ & $195 \mathrm{Ab}$ & $146 \mathrm{Ac}$ & $202 \mathrm{Aa}$ & $181 \mathrm{Ab}$ & $134 \mathrm{Ac}$ \\
\hline & 48 & $209 \mathrm{Aa}$ & $193 \mathrm{Aa}$ & $73 \mathrm{Bb}$ & $201 \mathrm{Aa}$ & $193 \mathrm{Aa}$ & $75 \mathrm{Bb}$ \\
\hline & 96 & $214 \mathrm{Aa}$ & $185 \mathrm{Ab}$ & $46 \mathrm{Cc}$ & $201 \mathrm{Aa}$ & $168 \mathrm{Bb}$ & $41 \mathrm{Cc}$ \\
\hline \multirow{4}{*}{$\begin{array}{l}\text { Controlled } \\
\text { stored }\end{array}$} & & & & & & & \\
\hline & 24 & $216 \mathrm{Aa}$ & $179 \mathrm{Ab}$ & $164 \mathrm{Ab}$ & $218 \mathrm{Aa}$ & $183 \mathrm{Ab}$ & $180 \mathrm{Ab}$ \\
\hline & 48 & $219 \mathrm{Aa}$ & $208 \mathrm{Ba}$ & $92 \mathrm{Bb}$ & $204 \mathrm{Aa}$ & $212 \mathrm{Ba}$ & $92 \mathrm{Bb}$ \\
\hline & 96 & $208 \mathrm{Aa}$ & $187 \mathrm{ABa}$ & $68 \mathrm{Cb}$ & $202 \mathrm{Aa}$ & $206 \mathrm{ABa}$ & $64 \mathrm{Bb}$ \\
\hline
\end{tabular}

y Inoculation of the fruits with Penicillium expansum 24, 48, and $96 \mathrm{~h}$ after treatment with yeast antagonist.

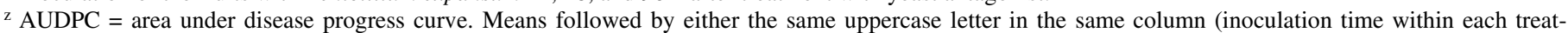
ment) or by the same lowercase letter in the same row (treatment within each time) are not statistically different when compared using orthogonal contrasts $(P=0.05)$.

TABLE 2. Effect of low dose UV-C irradiation on the progress of blue mold of cv. Red Delicious apples in storage

\begin{tabular}{|c|c|c|c|c|c|}
\hline \multirow[b]{2}{*}{ Treatment $^{\mathrm{x}}$} & \multirow[b]{2}{*}{ Time $^{y}$} & \multicolumn{2}{|c|}{ Repetition $\mathrm{I}^{\mathrm{z}}$} & \multicolumn{2}{|c|}{ Repetition $\mathrm{II}^{\mathrm{z}}$} \\
\hline & & Control AUDPC & UV-C AUDPC & Control AUDPC & UV-C AUDPC \\
\hline \multirow[t]{3}{*}{ Fresh } & 24 & 149 Аa & $96 \mathrm{Ab}$ & $161 \mathrm{Aa}$ & $81 \mathrm{Ab}$ \\
\hline & 48 & $144 \mathrm{Aa}$ & $45 \mathrm{Bb}$ & 149 Aa & $38 \mathrm{Bb}$ \\
\hline & 96 & $139 \mathrm{Aa}$ & $53 \mathrm{Bb}$ & $152 \mathrm{Aa}$ & $47 \mathrm{Bb}$ \\
\hline \multirow[t]{3}{*}{ CA-stored } & 24 & $161 \mathrm{Aa}$ & $120 \mathrm{Ab}$ & $181 \mathrm{Aa}$ & $133 \mathrm{Ab}$ \\
\hline & 48 & $169 \mathrm{Aa}$ & $97 \mathrm{Bb}$ & $189 \mathrm{Aa}$ & $106 \mathrm{Bb}$ \\
\hline & 96 & $153 \mathrm{Aa}$ & $96 \mathrm{Bb}$ & $169 \mathrm{Aa}$ & $96 \mathrm{Bb}$ \\
\hline
\end{tabular}

\footnotetext{
${ }^{\mathrm{x}}$ Freshly harvested or controlled atmosphere (CA)-stored fruits were either not irradiated with UV-C (controls) or irradiated with UV-C.

y Fruits were inoculated with Penicillium expansum 24, 48, or $96 \mathrm{~h}$ after treatment.

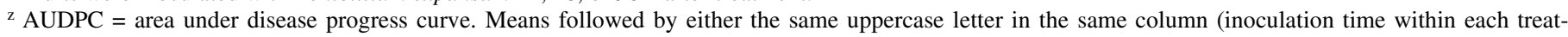
ment) or by the same lowercase letter in the same row (treatment within each time) are not statistically different when compared using orthogonal contrasts $(P=0.05)$.
} 


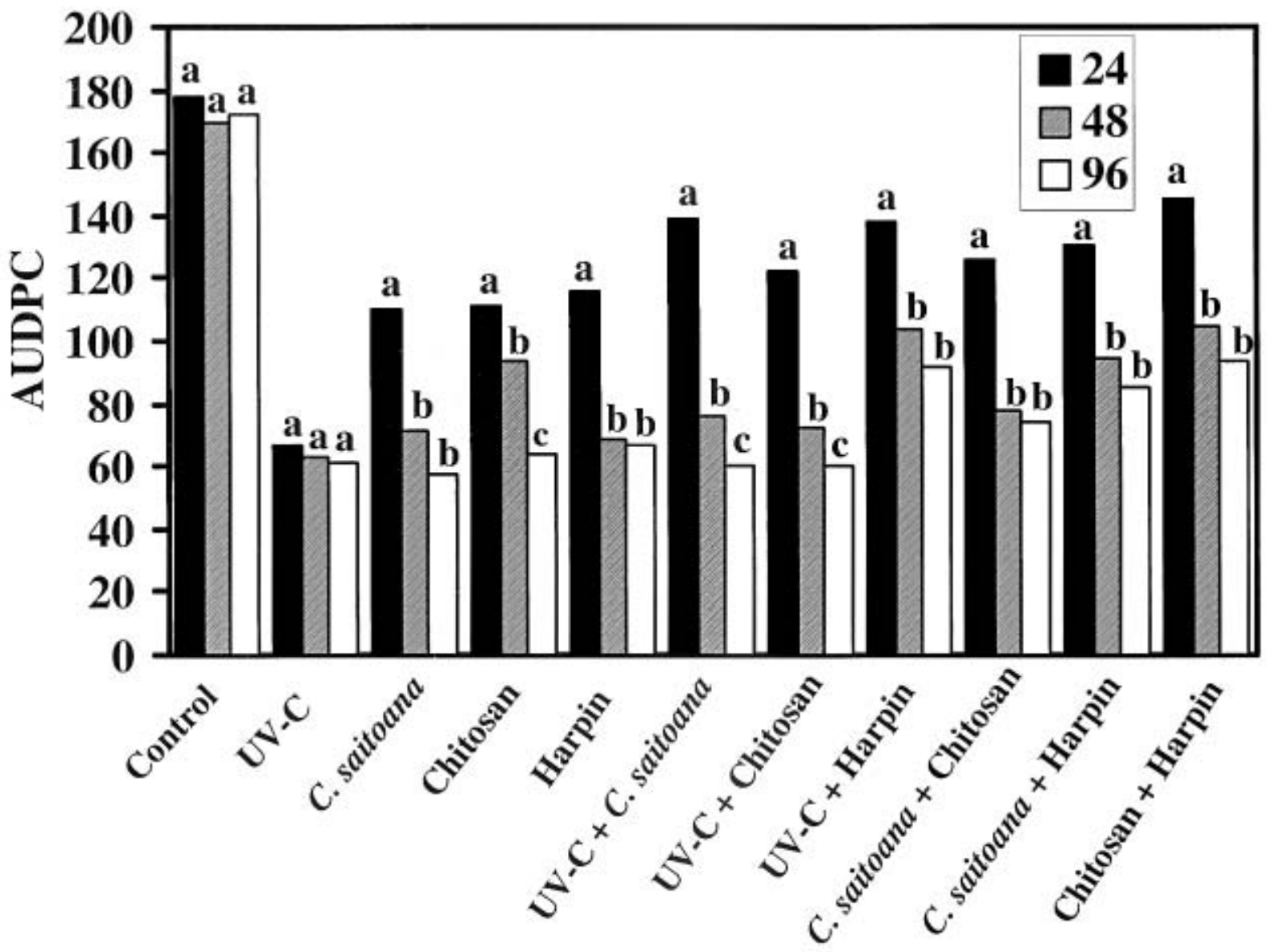

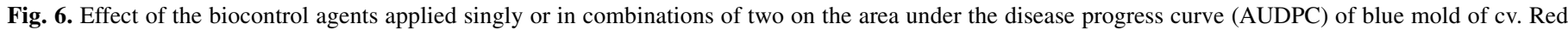

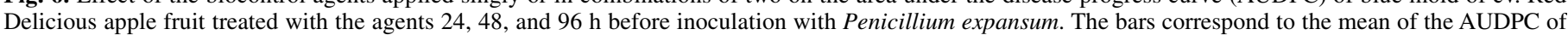

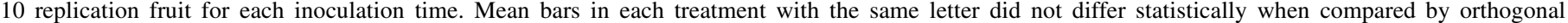
contrasts $(P=0.05)$.

Although the combination of treatments was overall less effective than the single treatments, they did provide significant reductions in the progress of disease in comparison with the controls.

\section{DISCUSSION}

All four agents tested in this study reduced the severity of blue mold lesions on apples by inducing resistance in the fruit rather than by directly affecting the pathogen, because no contact between pathogen and control agent took place. A time-dependent response was observed for most agents, indicating that treated fruit are able to resist the disease if they have enough time to develop mechanisms necessary for stopping or slowing the ingress and advance of the pathogen. All treatments either prevented or delayed the appearance of blue mold lesions. However, lesions that developed in the harpin-treated fruit did so at slower rates than the controls. Interestingly, fruit that had been stored in CA storage did not respond as strongly to the treatments with control agents as did freshly harvested fruit.

Resistance induced by chitosan in apple fruit against blue mold was concentration-dependent and depended on the time between treatment and inoculation. Control of plant diseases using chitosan, UV-C, yeast antagonists, and harpin has complex and diverse modes of action $(3,4,6)$. Chitosan has been shown to induce in several plants the accumulation of chitinase and $\beta$-1,3-glucanase $(7,12)$, salicylic acid (24), and phytoalexins (22); these molecules putatively are involved in resistance. Chitosan also induces structural changes that interfere with pathogen colonization (6). These effects are consistent with the present results and reinforce the conclusion that chitosan reduces the damage caused by a wide range of pathogens on a wide range of commodities.

We found that UV-C induced resistance within the first $24 \mathrm{~h}$ following treatment. However, greater control was achieved when fruit were treated 48 or $96 \mathrm{~h}$ before inoculation. UV-C irradiation, besides being germicidal and causing delayed ripening of fruit, elicits biochemical responses in host tissue $(1,15,19,20)$. The present results are in agreement with those of Mercier et al. (15), who showed that bell pepper fruit treated with UV-C $24 \mathrm{~h}$ prior to inoculation with Botrytis cinerea, had a smaller percentage of infections than did the controls, suggesting that this result was due to induction of resistance mechanisms. In our tests, UV-C was more effective in controlling blue mold than most of the other control agents. This effect may be because UV treatment was applied to the whole surface of the fruit, rather than to a small area, as were the other control agents. Mercier et al. (16) showed that induction of resistance in UV-treated carrots was limited to the irradiated area and that no systemic resistance occurred. We suspect that applying the other control agents to the whole fruit surface, rather than to small areas of the surface, would increase resistance.

The present study showed that $C$. saitoana induced resistance against blue mold in apple. In contrast to previous investigations, in this study the yeast cells were placed on the surface of fruit at $1 \mathrm{~cm}$ from the inoculated wound, and although the yeast cells may have been able to grow on the fruit surface, both preliminary and included tests indicated that they did not reach the inoculation wounds or their immediate vicinity within the time frame of the experiment. This result and the basic design of the experiment, 
TABLE 3. Comparison between the area under disease progress curve (AUDPC) means of the treatments applied singly and in combinations ${ }^{\mathrm{y}}$

\begin{tabular}{|c|c|c|c|c|c|c|c|c|c|c|c|c|c|c|c|c|c|c|c|}
\hline \multirow[b]{2}{*}{ Singly } & \multirow[b]{2}{*}{ Time $^{z}$} & \multicolumn{3}{|c|}{ UV-C+C. saitoana } & \multicolumn{3}{|c|}{ UV-C+chitosan } & \multicolumn{3}{|c|}{ UV-C+harpin } & \multicolumn{3}{|c|}{ C. saitoana+chitosan } & \multicolumn{3}{|c|}{ C. saitoana+harpin } & \multicolumn{3}{|c|}{ Chitosan+harpin } \\
\hline & & $\begin{array}{c}24 \\
(139)\end{array}$ & $\begin{array}{c}48 \\
(76)\end{array}$ & $\begin{array}{c}96 \\
(60)\end{array}$ & $\begin{array}{c}24 \\
(122)\end{array}$ & $\begin{array}{c}48 \\
(72)\end{array}$ & $\begin{array}{c}96 \\
(60)\end{array}$ & $\begin{array}{c}24 \\
(138)\end{array}$ & $\begin{array}{c}48 \\
(103)\end{array}$ & $\begin{array}{c}96 \\
(91)\end{array}$ & $\begin{array}{c}24 \\
(126)\end{array}$ & $\begin{array}{c}48 \\
(78)\end{array}$ & $\begin{array}{c}96 \\
(94)\end{array}$ & $\begin{array}{c}24 \\
(132)\end{array}$ & $\begin{array}{c}48 \\
(95)\end{array}$ & $\begin{array}{c}96 \\
(85)\end{array}$ & $\begin{array}{c}24 \\
(145)\end{array}$ & $\begin{array}{c}48 \\
(105)\end{array}$ & $\begin{array}{c}96 \\
(94)\end{array}$ \\
\hline \multirow[t]{3}{*}{ UV-C } & $24(64)$ & $* * *$ & & & $* * *$ & & & $* * *$ & $* * *$ & $* * *$ & $* * *$ & & $* * *$ & $* * *$ & $* * *$ & $* *$ & $* * *$ & $* * *$ & $* * *$ \\
\hline & $48(63)$ & $* * *$ & & & $* * *$ & & & $* * *$ & $* * *$ & $* * *$ & $* * *$ & & $* * *$ & $* * *$ & $* * *$ & $* *$ & $* * *$ & $* * *$ & $* * *$ \\
\hline & $96(61)$ & $* * *$ & & & $* * *$ & & & $* * *$ & $* * *$ & $* * *$ & $* * *$ & $*$ & $* * *$ & $* * *$ & $* * *$ & $* *$ & $* * *$ & $* * *$ & $* * *$ \\
\hline \multirow[t]{3}{*}{ US-240 } & $24(110)$ & $* * *$ & $* * *$ & $* * *$ & & $* * *$ & $* * *$ & $* * *$ & & $*$ & $*$ & $* * *$ & $*$ & $* * *$ & $*$ & $* *$ & $* * *$ & & $*$ \\
\hline & $48(71)$ & $* * *$ & & & $* * *$ & & & $* * *$ & $* * *$ & $*$ & $* * *$ & & $* *$ & $* * *$ & $* *$ & & $* * *$ & $* * *$ & $* *$ \\
\hline & $96(57)$ & $* * *$ & $*$ & & $* * *$ & & & $* * *$ & $* * *$ & $* * *$ & $* * *$ & $*$ & $* * *$ & $* * *$ & $* * *$ & $* * *$ & $* * *$ & $* * *$ & $* * *$ \\
\hline \multirow[t]{3}{*}{ Chitosan } & $24(111)$ & $* * *$ & $* * *$ & $* * *$ & & $* * *$ & $* * *$ & $* * *$ & & $*$ & & $* * *$ & $*$ & $* * *$ & $*$ & $* * *$ & $* * *$ & & $*$ \\
\hline & 48 (93) & $* * *$ & $*$ & $* * *$ & $* * *$ & $* *$ & $* * *$ & $* * *$ & & & $* * *$ & $*$ & & $* * *$ & & & $* * *$ & & \\
\hline & $96(64)$ & $* * *$ & & & $* * *$ & & & $* * *$ & $* * *$ & $* * *$ & $* * *$ & & $* * *$ & $* * *$ & $* * *$ & $* *$ & $* * *$ & $* * *$ & $* * *$ \\
\hline \multirow[t]{3}{*}{ Harpin } & $24(115)$ & $* *$ & $* * *$ & $* * *$ & & $* * *$ & $* * *$ & $* * *$ & & $* *$ & & $* * *$ & $* *$ & $* * *$ & $* *$ & $* * *$ & $* * *$ & & $* *$ \\
\hline & $48(69)$ & $* * *$ & & & $* * *$ & & & $* * *$ & $* * *$ & $* *$ & $* * *$ & & $* *$ & $* * *$ & $* *$ & $*$ & $* * *$ & $* * *$ & $* *$ \\
\hline & $96(67)$ & $* * *$ & & & $* * *$ & & & $* * *$ & $* * *$ & $* *$ & $* * *$ & & $* * *$ & $* * *$ & $* * *$ & $*$ & $* * *$ & $* * *$ & $* * *$ \\
\hline
\end{tabular}

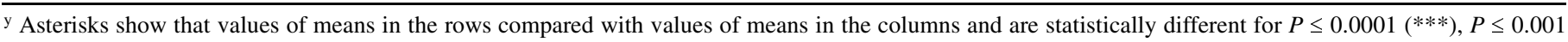
(**), and $P \leq 0.05$ (*).

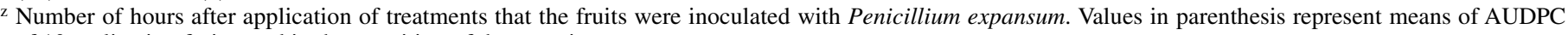
of 10 replication fruits used in the repetition of the experiment.

separated any possible direct effect that the yeasts might have on $P$. expansum from effects on the fruit that induce resistance to disease. Thus, we conclude that applying yeast cells to the fruit surface at $48 \mathrm{~h}$, and preferably $96 \mathrm{~h}$, before inoculation resulted in significant disease control due to induction of systemic resistance mechanisms. Biological control with yeast antagonists seems to be very dynamic, because it may involve the microecology of the pathogen and antagonist, direct action of the antagonist on the pathogen, as well as resistance responses of the host $(4,6)$. Usually the basic mechanisms involved are (i) direct competition between pathogen and antagonist at the wound site for nutrients and space $(4,32)$; (ii) attachment of the yeast to the cell walls of the pathogen and production of pathogen cell wall-degrading enzymes (35); and (iii) elicitation of defensive enzymes and structural barriers in the host (induced resistance) against the pathogen (11). Among these three possible modes of action, the least studied is induced resistance.

Harpin induces a hypersensitive response and systemic acquired resistance in tobacco, Arabidopsis, and other plants (3). However, few studies have been done to test its ability to induce resistance in harvested commodities. In this study, we showed that harpin induces resistance in apple fruit against blue mold, and that resistance depends on harpin concentration and the interval between treatment and inoculation. Dong et al. (3) demonstrated that harpin induces the expression of pathogenesis-related (PR) genes and other early response activators including active oxygen species in Arabidopsis. Their studies also indicated that resistance is systemic and that resistance response mediators are activated in as little as a few minutes following treatment with harpin. We suspect that the expression of PR genes is one of the mechanisms by which harpin acts on harvested apples. Cytological studies currently underway on harpin-treated fruit have shown that harpin induces structural changes in the cell wall and internally in epidermal cells and adjacent parenchyma cells. We suspect that these changes are related to the development of disease resistance $(\mathrm{G}$. de Capdeville, C. L. Wilson, S. V. Beer, and J. R. Aist, unpublished data).

In our tests of various combinations of UV-C, yeast, chitosan, and harpin, we found no evidence of any synergistic effect on reducing the progress of blue mold. However, small additive effects were detected for some of the combinations. Although the results of the treatments using combined agents were not always as satisfactory as when the agents were used singly, none of the combinations of agents should be considered antagonistic. Indeed, the combination of treatments provided considerable reduction in the disease progress compared with the controls, especially for the inoculation times of 48 and $96 \mathrm{~h}$. Moreover, they were not different from the single treatments in many situations, and indeed, combinations of UV-C plus chitosan and of $C$. saitoana plus chitosan generated additive effects compared with the two treatments used alone. Perhaps combining the treatments that yielded the greatest reductions when used singly may have obscured potential additive or synergistic effects of other possible combinations. Indeed, it is possible that combining smaller doses or concentrations of the agents, together with different times of applications, may produce useful additive or synergistic effects. Among the control agents evaluated in this study, only harpin was not previously studied separately or combined with another biocontrol agent to search for possible additive or synergistic effects of the combination. As for the other control agents, some combinations have been tested in the studies by El-Ghaouth et al. $(9,10)$, Stevens et al. (28), and Sugar et al. (30).

The results of this study support the notion that induced resistance is a common mode of action for these alternative control agents, and may be a worthwhile strategy for postharvest disease control. The effects of these agents on blue mold make them potentially suitable for use in integrated pest management strategies, because they offer great potential for minimizing postharvest decay while reducing the risks associated with the, sometimes, excessive use of traditional fungicidal chemicals.

\section{ACKNOWLEDGMENTS}

This research was supported primarily by the Cornell Agricultural Experiment Station Federal formula funds, Project NYC-153410, and in part by an Arthur Boller Research Grant, both received from Cooperative State Research, Education and Extension Service, U.S. Department of Agriculture. Any opinions, findings, conclusions, or recommendations expressed in this publication are those of the authors and do not reflect the view of the U.S. Department of Agriculture. G. de Capdeville was supported by the Conselho Nacional de Desenvolvimento Científico e tecnológico $(\mathrm{CNPq})$ during the completion of his $\mathrm{Ph} . \mathrm{D}$. program at Cornell University. We thank L. O. Tedeschi of the Department of Animal Science, Cornell University, and S. J. Schwager of the Department of Biometrics, Cornell University, for their help with the statistical analyses.

\section{LITERATURE CITED}

1. D’Hallewin, G., Schirra, M., Manueddu, E., Piga, A., and Ben, Y. S. 1999. Scoparone and scopoletin accumulation and ultraviolet-C induced resistance to postharvest decay in oranges as influenced by harvest date. 
J. Am. Soc. Hortic. Sci. 124:702-707.

2. Dhingra, O. D., and Sinclair, J. B. 1985. Basic Plant Pathology Methods. CRC Press, Boca Raton, FL.

3. Dong, H., Delaney, T. P., Bauer, D. W., and Beer, S. V. 1999. Harpin induces disease resistance in Arabidopsis through the systemic acquired resistance pathway mediated by salicylic acid and the NIM 1 gene. Plant J. 20:207-215.

4. Droby, S., and Chalutz, E. 1994. Mode of action of biocontrol agents of postharvest diseases. Pages 63-75 in: Biological Control of Postharvest Diseases: Theory and Practice. C. L. Wilson and M. E. Wisniewski, eds. CRC Press, Boca Raton, FL.

5. Droby, S., Cohen, L., Daus, A., Weiss, B., Horev, B., Chalutz, E., Katz, H., Keren-Tzur, M., and Shachnai, A. 1998. Commercial testing of aspire: A yeast preparation for the biological control of postharvest decay of citrus. Biol. Control 12:97-101.

6. El Ghaouth, A. 1994. Manipulation of defense systems with elicitors to control postharvest diseases. Pages 153-167 in: Biological Control of Postharvest Diseases: Theory and Practice. C. L. Wilson and M. E. Wisniewski, eds. CRC Press, Boca Raton, FL.

7. El Ghaouth, A. 1997. Biologically-based alternatives to synthetic fungicides for the control of postharvest diseases. J. Ind. Microbiol. Biotechnol. 19:160-162.

8. El Ghaouth, A., Arul, J., Ponnampalam, R., and Boulet, M. 1991. Chitosan coating effect on storability and quality of fresh strawberries. J. Food Sci. 56:1618-1620.

9. El Ghaouth, A., Smilanick, J. L., Brown, G. E., Ippolito, A., Wisniewski, M., and Wilson, C. L. 2000. Application of Candida saitoana and glycolchitosan for the control of postharvest diseases of apple and citrus fruit under semi-commercial conditions. Plant Dis. 84:243-248.

10. El Ghaouth, A., Smilanick, J. L., Wisniewski, M., and Wilson, C. L. 2000. Improved control of apple and citrus fruit decay with a combination of Candida saitoana and 2-deoxy-D-glucose. Plant Dis. 84:249-253.

11. El Ghaouth, A., Wilson, C. L., and Wisniewski, M. E. 1998. Ultrastructural and cytochemical aspects of the biological control of Botrytis cinerea by Candida saitoana in apple fruit. Phytopathology 88:282-291.

12. Fajardo, J. E., McCollum, T. G., McDonald, R. E., and Mayer, R. T. 1998. Differential induction of proteins in orange flavedo by biologically based elicitors and challenged by Penicillium digitatum Sacc. Biol. Control 13:143-151.

13. Janisiewicz, W. J., and Bors, B. 1995. Development of a microbial community of bacterial and yeast antagonists to control wound-invading postharvest pathogens of fruits. Appl. Environ. Microbiol. 61:32613267.

14. Kuehl, R. O. 2000. Design of Experiments: Statistical Principles of Research Design and Analysis. 2nd ed. Duxbury Press, New York.

15. Mercier, J., Baka, M., Reddy, B., Corcuff, R., and Arul, J. 2001. Shortwave ultraviolet irradiation for control of decay caused by Botrytis cinerea in bell pepper: Induced resistance and germicidal effects. J. Am. Soc. Hortic. Sci. 126:128-133.

16. Mercier, J., Roussel, D., Charles, M.-T., and Arul, J. 2000. Systemic and local responses associated with UV- and pathogen-induced resistance to Botrytis cinerea in stored carrot. Phytopathology 90:981-986.

17. Mercier, J., and Wilson, C. L. 1994. Colonization of apple wounds by naturally occurring microflora and introduced Candida oleophila and their effect on infection by Botrytis cinerea during storage. Biol. Control 4:138-144.

18. Neter, J., Kutner, M. H., Nachtsheim, C. J., and Wasserman, W. 1996.
Applied Linear Statistical Models. 4th ed. McGraw-Hill Publishing, Boston.

19. Nigro, F., Ippolito, A., Lattanzio, V., Di, V. D., and Salerno, M. 2000. Effect of ultraviolet-C light on postharvest decay of strawberry. J. Plant Pathol. 82:29-37.

20. Porat, R., Lers, A., Dori, S., Cohen, L., Weiss, B., Daus, A., Wilson, C. L., and Droby, S. 1999. Induction of chitinase and beta-1,3-endoglucanase proteins by UV irradiation and wounding in grapefruit peel tissue. Phytoparasitica 27:233-238.

21. Prusky, D., Bazak, M., and R., Ben-Arie. 1985. Development, persistence, survival, and strategies for control of thiabendazole-resistant strains of Penicillium expansum on pome fruit. Phytopathology 75:877882.

22. Reddy, M. V. B., Angers, P., Castaigne, F., and Arul, J. 2000. Chitosan effects on blackmold rot and pathogenic factors produced by Alternaria alternata in postharvest tomatoes. J. Am. Soc. Hortic. Sci. 125:742-747.

23. Rosenberger, D. A., Ahlers, C. A., and Meyer, F. W. 2001. Penicillium expansum invades Empire apples through stems during long term controlled atmosphere storage. (Abstr.) Phytopathology 91(suppl.):S197.

24. Sathiyabama, M., and Balasubramanian, R. 1998. Chitosan induces resistance components in Arachis hypogaea against leaf rust caused by Puccinia arachidis Speg. Crop Prot. 17:307-313.

25. Shaner, G., and Finney, R. E. 1977. The effect of nitrogen fertilization on the expression of slow mildewing resistance in knox wheat. Phytopathology 67:1051-1056.

26. Snowdon, A. L. 1990. Color Atlas of Post-Harvest Diseases and Disorders of Fruit and Vegetables, Vol. 1. CRC Press, Boca Raton, FL.

27. Stevens, C., Khan, V. A., Lu, J. Y., Wilson, C. L., Chalutz, E., Droby, S., Kabwe, M. K., Haung, Z., Adeyeye, O., Pusey, L. P., and Tang, A. Y. A. 1999. Induced resistance of sweetpotato to Fusarium root rot by UV-C hormesis. Crop Prot. 18:463-470.

28. Stevens, C., Khan, V. A., Lu, J. Y., Wilson, C. L., Pusey, P. L., Igwegbe, E. C. K., Kabwe, K., Mafolo, Y., Liu, J., Chalutz, E., and Droby, S. 1997. Integration of ultraviolet (UV-C) light with yeast treatment for control of postharvest storage rots of fruit and vegetables. Biol. Control 10:98-103.

29. Stevens, C., Wilson, C. L., Lou, J. Y., Khan, V. A., Chalutz, E., Droby, S., Kabwe, M. K., Haung, Z., Adeyeye, O., Pusey, L. P., Wisniewski, M. E., and West, M. 1996. Plant hormesis induced by ultraviolet light-C for controlling postharvest diseases of tree fruit. Crop Prot. 15:129-134.

30. Sugar, D., Roberts, R. G., Hilton, R. J., Righetti, T. L., and Sanchez, E. E. 1994. Integration of cultural methods with yeast treatment for control of postharvest fruit decay in pear. Plant Dis. 78:791-795.

31. Sugar, D., and Spotts, R. A. 1999. Control of postharvest decay in pear by four laboratory-grown yeasts and two registered biocontrol products. Plant Dis. 83:155-158.

32. Usall, J., Teixido, N., Fons, E., and Vinas, I. 2000. Biological control of blue mould on apple by a strain of Candida sake under several controlled atmosphere conditions. Int. J. Food Microbiol. 58:83-92.

33. Wilson, C. L., El Ghaouth, A., Chalutz, E., Droby, S., Stevens, C., Lu, J. Y., Khan, V., and Arul, J. 1994. Potential of induced resistance to control postharvest diseases of fruit and vegetables. Plant Dis. 78:837-844.

34. Wilson, C. L., Wisniewski, M. E., Droby, S., and Chalutz, E. 1993. A selection strategy for microbial antagonists to control postharvest diseases of fruit and vegetables. Sci. Hortic. 53:183-189.

35. Wisniewski, M., Biles, C., Droby, S., McLaughlin, R., Wilson, C., and Chalutz, E. 1991. Mode of action of the post-harvest biocontrol yeast Pichia guilliermondii. I. Characterization of attachment to Botrytis cinerea. Physiol. Mol. Plant Pathol. 39:245-258. 